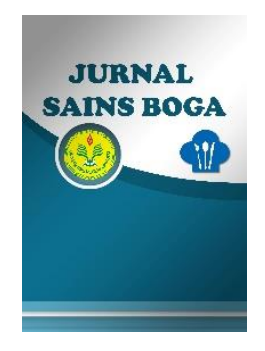

\title{
PENGARUH TEKNIK PEMANASAN BASAH DALAM PEMBUATAN ONCOM INSTAN TERHADAP KUALITAS TUMIS ONCOM
}

\author{
Imaduddin Zamakhsyari ${ }^{1, *}$, Alsuhendra ${ }^{1)}$, Ridawati ${ }^{1)}$ \\ 1) Program Studi Pendidikan Tata Boga, Fakultas Teknik, Universitas Negeri Jakarta \\ *) corresponding author: imaduddinzamakhsyari@gmail.com
}

\begin{abstract}
The aim of this research is to know the effect of wet heating technique in oncom instant making to the quality of oncom stir-fry. The research held in Pastry Laboratory, Culinary Department, Faculty of Engineering, State University of Jakarta on August 2016 until January 2017. The Research was using experimental method. The Technique of boiling, the high pressure and the steam to the quality of stir-fry oncom.The result data from the panelist evaluation analyzed with kruskal-wallis test on significant level $\alpha=0,05$. The result of hypothesis testing with kruskal-wallis test indicated the insignificant effect for the quality of stir-fry oncom sensorial, which cover the color, aroma, and texture, taste aspect. Therefore, the stir-fry oncom product with presto technique was recommended.
\end{abstract}

Key Words : Instant Oncom, Quality, Wet heating technique

\begin{abstract}
ABSTRAK
Penelitian ini bertujuan untuk mengetahui dan menganalisis pengaruh teknik pemanasan basah dalam pembuatan oncom instan terhadap kualitas tumis oncom. Penelitian ini dilakukan di Laboratorium pastry, Program Studi Tata Boga, Fakultas Teknik, Universitas Negeri Jakarta pada bulan Agustus 2016 sampai Februari 2017. Penelitian ini menggunakan metode eksperimen. Pemanasan basah teknik rebus, teknik presto teknik kukus. Data hasil penilaian panelis dianalisis dengan menggunakan uji kruskal-wallis pada taraf signifikan $\alpha=0,05$. hasil pengujian hipotesis dengan uji kruskal-wallis menunjukkan tidak adanya pengaruh yang signifikan terhadap mutu sensoris tumis oncom yang meliputi aspek warna, aroma, rasa, dan tekstur.
\end{abstract}

Kata Kunci : oncom instan, kualitas, teknik pemanasan basah

\section{PENDAHULUAN}

Oncom merupakan produk fermentasi dari bahan baku limbah, yaitu bungkil kacang tanah dan ampas tahu atau onggok (sisa pembuatan aci atau tapioka) (Sarwono, 2007). Dikalangan masyarakat oncom kurang diminati dibandingkan hasil olahan kacang-kacangan yang lain, 
seperti tahu dan tempe. Pandangan negatif tersebut muncul karena oncom terbuat dari ampas tahu atau bungkil kacang tanah. Namun oncom memiliki nilai dan mutu gizi yang baik akibat proses fermentasi.

Dengan adanya proses fermentasi, maka struktur kimia bahan-bahan yang tadinya bersifat kompleks akan terurai menjadi senyawa-senyawa yang lebih sederhana sehingga lebih mudah dicerna dan diserap oleh tubuh. Proses fermentasi oleh kapang juga menghasilkan komponen citarasa sehingga menjadi lebih disukai (Siswono, 2010).

Saat ini ada dua jenis oncom, yaitu oncom merah dan oncom hitam.Perbedaan kedua jenis oncom tersebut terletak pada jenis kapang(Sastraatmadja, 2010).

Oncom merah dihasilkan oleh kapang Neurospora sitophila yang mempunyai strain jingga, merah, merah muda, dan warna peach. Sedangkan oncom hitam dihasilkan oleh kapang Rhizopus oligosporus. Jadi, warna merah atau hitam pada oncom ditentukan oleh pigmen yang dihasilkan oleh kapang yang digunakan dalam proses fermentasi (Astawan, 2009).

Oncom merah memiliki nilai gizi yang cukup baik, berikut adalah nilai gizi oncom per 100 gram : Air (57 g), Kalori (187 g), Protein (13 g), Lemak (6 g), Karbohidrat (22,6 g), Kalsium (96 g), zat besi $(27 \mathrm{mg})$, Fosfor $(115 \mathrm{mg})$, Vitamin B $(0,09 \mathrm{mg})$. Oncom merah memiliki nilai jual yang lebih tinggi dibandingkan oncom hitam. Namun sifat oncom merah tidak tahan lama. Pada suhu ruang oncom merah hanya bertahan satu hari, sedangkan pada suhu kulkas dapat bertahan dua sampai tiga hari. untuk meningkatkan daya simpan oncom merah, maka oncom merah perlu diproses menjadi produk yang memiliki daya simpan tinggi(Hesseltine, 2008).

Penelitian ini menggunakan oncom merah yang diolah menjadi produk awetan, yaitu oncom instan. Oncom instan dibuat melalui proses pemanasan basah dan pengeringan. Proses pengawetan dan instanisasi ini bertujuan untuk mematikan kapang pada oncom merah. Oncom merah yang telah melalui proses pengawetan kemudian diaplikasikan pada tumis oncom.

Tumis oncom adalah salah satu oalahan oncom merah yang paling umum diolah dan digemari oleh masyarakat. Tumis oncom adalah salah satu makanan yang berbahan dasar oncom merah dengan tambahan bumbu tumis seperti cabe, bawang merah, bawang putih, dan leunca.Berdasarkan paparan maka penelitian ini dibuat untuk mengetahui pengaruh teknik pemanasan basah dalam Pembuatan Oncom Instan dan aplikasinya pada tumis oncom.

Berdasarkan latar belakang, peneliti tertarik dengan judul "Pengaruh Teknik Pemanasan Basah Dalam Pembuatan Oncom Instan Terhadap Kualitas Tumis Oncom”.

\section{METODE PENELITIAN}

Populasi dalam penelitian ini adalah pengaruh proses pmanasan basah terhadap kualitas oncom instan dengan aplikasinya pada tumis oncom. Perlakuan pemanasan basah teknik rebus, teknik presto, daan teknik kukus.

Pengambilan data analisis produk tersebut dilakukan dengan mengambil data melalui uji validitas yang melibatkan 5 orang dosen ahli, sedangkan untuk mengetahui kualitas produk dilakukan dengan uji kualitas yang meliputi aspek warna, aroma, rasa dan tekstur oleh 15 orang panelis untuk setiap kode sampelnya. Panelisyaitu mahasiswa Prodi Tata Boga, Fakultas Teknik Universitas Negeri Jakarta yang sudah menerima mata kuliah Pengawetan Bahan Makanan.

Data yang diperoleh akan diuji menggunakan uji kruskal-wallis dengan nilai rentang $0,05(5,99)$ dan jika terdapat pengaruh maka akan dilanjutkan dengan uji Tuckey's

\section{HASIL DAN PEMBAHASAN}

Hasil uji kualitas secara keseluruhan yang meliputi aspek warna, aroma, rasa, dan tekstur dengan hipotesis warna yang diharapkan adalah coklat, aroma agak kuat, rasa gurih,dan tekstur lunak. Berikut adalah hasil uji kualitas tumis oncom : 


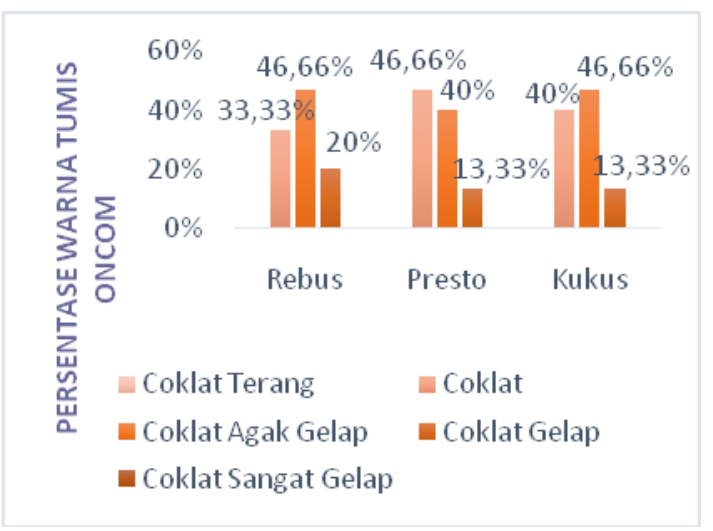

Gambar 1. Hasil Uji Deskriptif Aspek Warna Pengaruh Teknik Pemanasan Basah pada Pembuatan Oncom Instan Terhadap Kualitas Tumis Oncom

Hasil pengujian hipotesis pada aspek warna tumis oncom dengan nilai $\mathrm{x}^{2}$ hitung sebesar 0,59. Sedangkan nilai $x^{2}$ tabel adalah 5,99. Hal ini menunjukan bahwa $x^{2}$ hitung $<x^{2}$ tabel dimana berarti $\mathrm{H}_{\mathrm{o}}$ diterima, berdasarkan hasil hipotesis tersebut maka dapat dinyatakan bahwa tidak terdapat pengaruh teknikpemanasan basah pada pembuatan oncom instan terhadap kualitas tumis oncom.

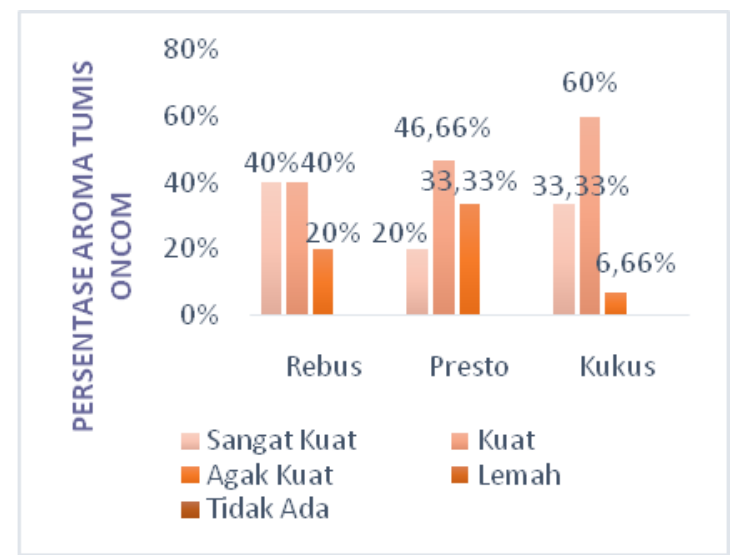

Gambar 2. Hasil Uji Deskriptif Aspek Aroma Pengaruh Teknik Pemanasan Basah pada Pembuatan Oncom Instan Terhadap Kualitas Tumis Oncom

Hasil pengujian hipotesis pada aspek aroma tumis oncom dengan nilai $x^{2}$ hitung sebesar 2,25. Sedangkan nilai $x^{2}$ tabel adalah 5,99. Hal ini menunjukan bahwa $x^{2}$ hitung $<x^{2}$ tabel dimana berarti $\mathrm{H}_{\mathrm{o}}$ diterima, berdasarkan hasil hipotesis tersebut maka dapat dinyatakan bahwa tidak terdapat pengaruh teknikpemanasan basah pada pembuatan oncom instan terhadap kualitas tumis oncom.

Hasil pengujian hipotesis pada aspek rasa tumis oncom dengan nilai $\mathrm{x}^{2}$ hitung sebesar 1,81 . Sedangkan nilai $\mathrm{x}^{2}$ tabel adalah 5,99. Hal ini menunjukan bahwa $\mathrm{x}^{2}$ hitung $<\mathrm{x}^{2}$ tabel dimana berarti $\mathrm{H}_{\mathrm{o}}$ diterima, berdasarkan hasil hipotesis tersebut maka dapat dinyatakan bahwa tidak terdapat pengaruh teknikpemanasan basah pada pembuatan oncom instan terhadap kualitas tumis oncom. 


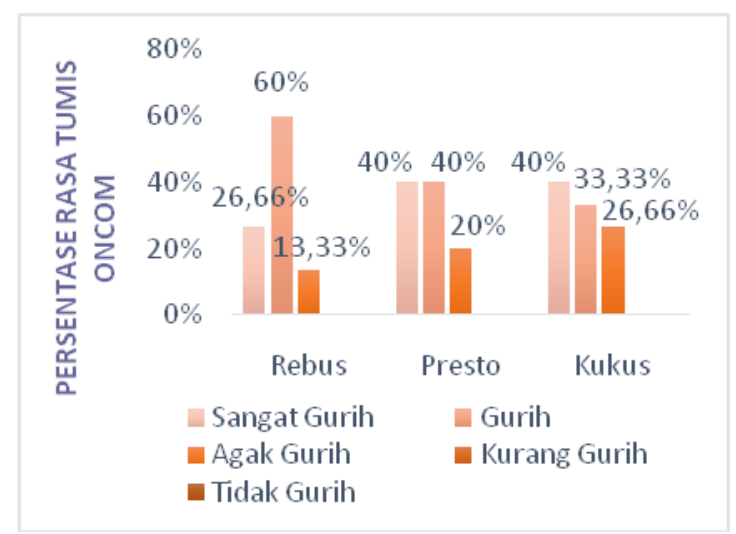

Gambar 3. Hasil Uji Deskriptif Aspek Rasa Pengaruh Teknik Pemanasan Basah pada Pembuatan Oncom Instan Terhadap Kualitas Tumis Oncom

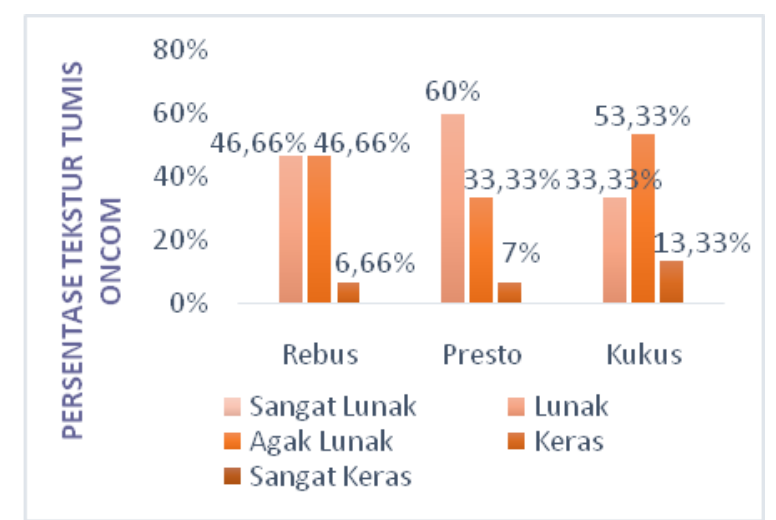

Gambar 4. Hasil Uji Deskriptif Aspek Tekstur Pengaruh Teknik Pemanasan Basah pada Pembuatan Oncom Instan Terhadap Kualitas Tumis Oncom

Hasil pengujian hipotesis pada aspek tekstur tumis oncom dengan nilai $\mathrm{x}^{2}$ hitung sebesar 1,78. Sedangkan nilai $x^{2}$ tabel adalah 5,99. Hal ini menunjukan bahwa $x^{2}$ hitung $<x^{2}$ tabel dimana berarti $\mathrm{H}_{\mathrm{o}}$ diterima, berdasarkan hasil hipotesis tersebut maka dapat dinyatakan bahwa tidak terdapat pengaruh teknikpemanasan basah pada pembuatan oncom instan terhadap kualitas tumis oncom.

\section{SIMPULAN}

Data yang didapatkan dari penilaian panelis sebanyak 45 orang hasil hipotesis penelitian menunjukkan bahwa Hasil pengujian hipotesis melalui uji kruskal-wallis, pengaruh teknik pemanasan basah dalam pembuatan oncom instan terhadap kualitas tumis oncom menunjukan tidak adanya pengaruh yang signifikan terhadap mutu sensoris tumis oncom yang meliputi aspek warna, aroma, rasa, dan tekstur.

Mengingat tujuan dari penelitian ini adalah untuk mengetahui dan menganalisis pengaruh teknik pemanasan basah dalam pembuatan oncom instan terhadap kualitas tumis oncom dapat disimpulkan bahwa pada aspek warna teknik presto merupakan yang paling baik. Sementara aspek aroma teknik presto tetap merupakan yang paling baik, sementara aspek rasa teknik rebus merupakan yang paling baik, dan aspek tekstur teknik presto merupakan yang paling baik. 
Secara umum semua perlakuan teknik pemanasan basah pada oncom instan tidak berbeda nyata sehingga dapat disimpulkan bahwa teknik pemanasan basah dalam pembuatan oncom instan dapat diterima sebagai bagian dari proses instanisasi oncom.

\section{DAFTAR PUSTAKA}

Astawan, Made. 2009. Kandungan Gizi Aneka Bahan Makanan. Jakarta: Gramedia.

Hesseltine, C.W., In: Proceedings of Conference on Soybean Products for Protein in Human Food., Peoria, 2008, pp $67-74$.

Sarwono, B. 2007. Membuat Tempe dan Oncom. Jakarta : Penebar Swadaya.

Siswono, “Oncom Menutup Kekurangan Energi dan Protein”, Gizinet, Jakarta, 2010.

Sastraatmadja DD, Tomita F, Kasai T., "Production of High-Quality Oncom, a Traditional Indonesian Fermented Food, by The Inoculation with Selected Mold Strains in The Form of Pure Culture and Solid Inoculums", J. Grad. Sch. Agr. Hokkaido Univ., 2010. vol. 70, pp. 111-127. 